\title{
Growth rate fitting using the von Bertalanffy model: analysis of natural populations of Drepanotrema spp. snails (Gastropoda: Planorbidae)
}

\author{
Alejandra Rumi, Diego E. Gutiérrez Gregoric \& M. Andrea Roche \\ División Zoología Invertebrados, Museo de La Plata, Facultad de Ciencias Naturales y Museo, Universidad Nacional \\ de La Plata, Paseo del Bosque s/nº, 1900 La Plata, Buenos Aires, Argentina. Fax: 540221 4257527; alerumi@fcnym. \\ unlp.edu.ar; dieguty@fcnym.unlp.edu.ar; rocheandrea@hotmail.com
}

Received 30-VII-2004. Corrected 31-V-2006. Accepted 12-I-2007.

\begin{abstract}
The genus Drepanotrema includes six species in Argentina. The life cycle in natural systems of Drepanotrema depressissimum, and D. lucidum has been little studied, except for some casual observations. The aim of this study is to analyze main population trends (age structures, recruitment periods, life span and curves of individual growth) in Paiva pond, Argentina. We explored growth model fitting and comparison methodologies between species and environments in Paiva pond and Isla Martín García (IMG), to determine interspecific patterns. Theoretical curves of von Bertalanffy's model for each population were contrasted with samplings using the $\chi^{2}$ test. Expected sizes were transformed into a percentage of maximum size and cohorts started from zero time, which allowed them to be independent of the real or estimated starting date and a comparison was possible. A similar time scale was used, because the $\mathrm{k}$ values proved to be sensitive to time scale. Maximum size reached by D. lucidum was $6.9 \mathrm{~mm}$ and by $D$. depressissimum $9.38 \mathrm{~mm}$. Growth rates (k) fluctuated from 1.302 to 1.368 in the first and 1.339 to 1.509 in the second species. No statistically significant differences were found in growth curves among species inhabiting the Paiva pond and in the different IMG water bodies independent of the beginning of each cohort and maximum size. In general, no winter cohorts were observed, except in one population of $D$. kermatoides (IMG). Comparing circannual and biannual growth rhythms most of the species reached $60 \%$ of their development during their first year, and $85 \%$ or more during their second year. Rev. Biol. Trop. 55 (2): 559-567. Epub 2007 June, 29.
\end{abstract}

Key words: growth-rates, Drepanotrema spp., Planorbidae, Argentina, Great Plata Basin.

Von Bertalanffy's growth model is widely applied in vertebrate populations, eg. in fish (Sendra and Freyre 1978, 1981, Colautti 1997), amphibians (Basso and Kehr 1991), as well as in bivalves (Ituarte 1985, Darrigran and Maroñas 1989, Boltovskoy and Cataldo 1999, Cataldo and Boltoskoy 1999). However, in freshwater gastropods the model has been applied mostly in experimental, field and/or laboratory studies and less under natural conditions (Baluku and Loreau 1989, Ferrer et al.1989, Perera de Puga et al. 1991, Pretorius et al. 1992, Costil and Daguzan 1995, Eleutheriadis and LazaridouDimitriadou 1995).

Among Planorbidae, the genus Biomphalaria Preston, 1910; has been most studied because it is an intermediate host of Schistosoma mansoni (Sambon, 1907). Population dynamics, structure and function of assemblages in the rest of the species of this family from Tropical and Subtropical regions has not received much attention.

The species of the genus Drepanotrema Fisher and Crosse, 1880; most of them endemic of the Neotropical Region and of a wide distribution, reach the northern part of the Nearctic Region (south of Texas, USA) (Baker 1945). In South America they form part of the most frequent freshwater snail associations and at present includes eight species. In spite of their abundance, the group has received scarce attention in relation with other genera of the 
Planorbidae family such as Biomphalaria due to its medical sanitary interest. Ecological aspects of Drepanotrema species are poorly known (Lévêque and Pointier 1976) and their morfo-anatomy and clasiffication have been scarcely revised (Baker 1945, Paraense and Deslandes 1958a, b and Paraense 1980, among others).

They are as frequent as Biomphalaria species in the macrosystem of the Great Plata Basin. In this basin, six genera of Planorbidae are present: Biomphalaria, Drepanotrema, Plesiophysa Fischer, 1883; Acrorbis Odhner, 1937; Antillorbis Harry and Hubendick, 1964 and Helisoma Swaison, 1840. The first two include the greatest number of species and are widely distributed in Argentina.

Drepanotrema includes six species in Argentina. The life cycle of $D$. depressissimum (Moricand, 1839) and D. lucidum (Pfeiffer, 1839) (Fig. 1) in natural sytems has been little studied, except for observations by Bonetto et al. (1982, 1990), Hamman et al. (1993), Rumi (1991) and Rumi et al. (2002).

The aims of our study were: 1 - To analyze the age structure of $D$. depressissimum and D. lucidum in Paiva pond, Corrientes, Argentina. 2- To identify recruitment periods and individual growth trends. 3- To estimate cohort life spans. 4- To explore the methodologies of growth model fitting in different species and environments: Paiva pond and Isla Martín García Reserve (IMG) (D. kermatoides (d'Orbigny, 1835) and D. cimex (Moricand, 1839) (Fig. 1), in order to determine interspecific patterns.

\section{MATERIALS AND METHODS}

Sites: Paiva pond, Pampín Place $\left(27^{\circ}\right.$ $30^{\prime} \mathrm{S}, 58^{\circ} 45^{\prime} \mathrm{W}$ ), belongs to the basin of
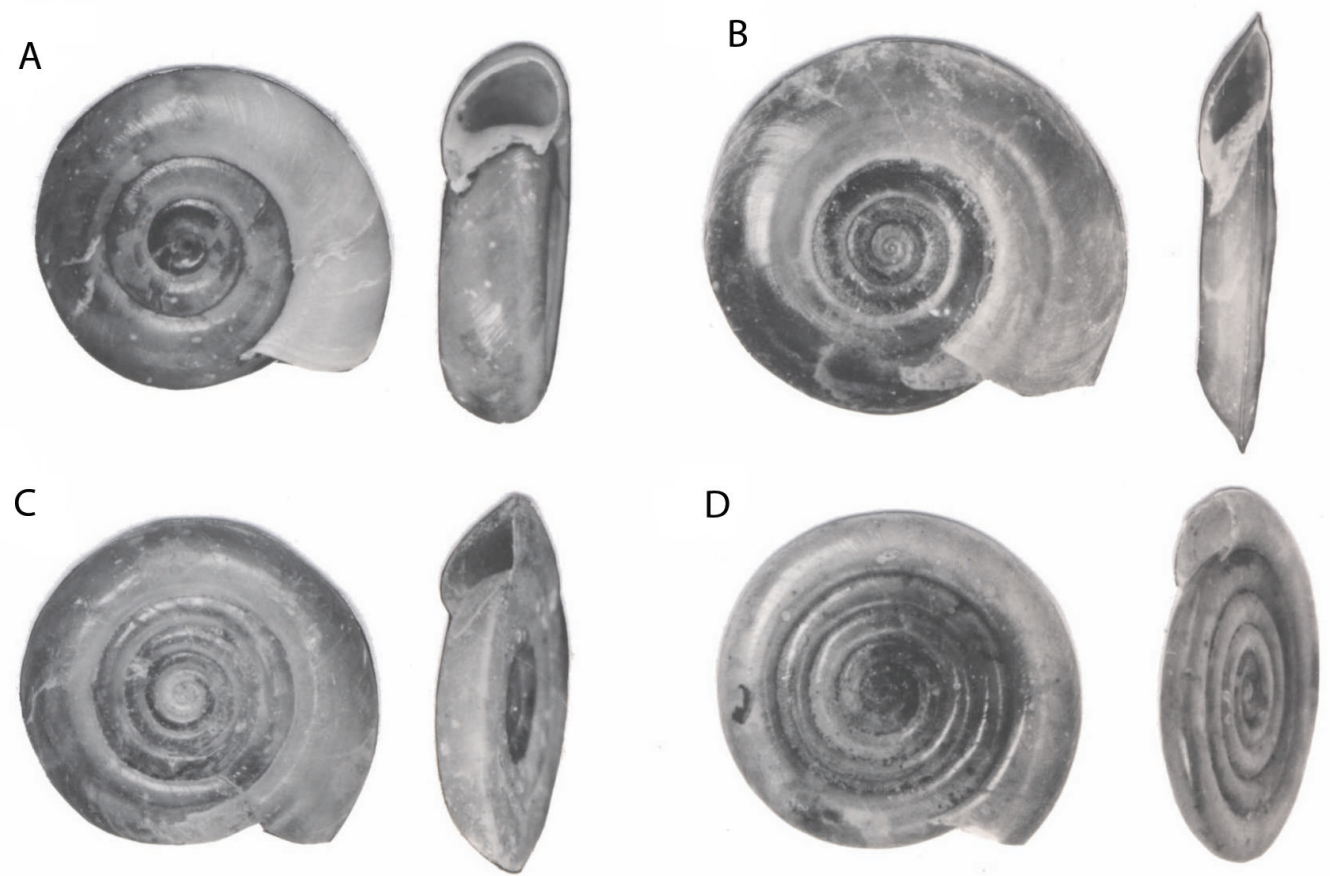

Fig. 1. Shells in dorsal and lateral view. A. D. lucidum, diameter $=5.35 \mathrm{~mm}$. B. D. depressissimum, diameter $=8.20 \mathrm{~mm}$. C. D. kermatoides, diameter $=5.40 \mathrm{~mm}$. D. D. cimex, diameter $=5.25 \mathrm{~mm}$.

Fig. 1. Conchillas en vista dorsal y lateral. A. D. lucidum, diámetro $=5.35 \mathrm{~mm}$. B. D. depressissimum, diámetro= $8.20 \mathrm{~mm}$. C. D. kermatoides, diámetro $=5.40 \mathrm{~mm}$. D. D. cimex, diámetro $=5.25 \mathrm{~mm}$. 
Riachuelo River, one of the main affluent of the Middle Paraná River, Corrientes, Argentina. It is in wetlands located in a low and discontinuous area (Bonetto et al. 1978a, b). Aquatic vegetation is distributed in patches and at different depths. In the littoral zone, macrophytes were associated with Drepanotrema populations. Three types of macrophytes could be distinguished: rooted plants, eg. Eleocharis minima, Scirpus cubensis, Ludwigia peploides and Hydrocotyle ranunculoides; free-floating plants eg. Salvinia herzogii, S. minima, Ricciocarpus natans, Azolla carolineana, Pistia stratiotes, Eichhornia azurea and Lemnaceae (Spirodella sp., Lemna sp., Wolffia sp. and Wolffiella sp.); and submerged plants eg. Cabomba australis, Potamogeton cf. illinoensis, Hydrocleys nymphoides, Nymphaea sp. and Utricularia oligosperma.

Sampling strategy: thirteen samples were taken between April 1986 and August 1987 in the littoral zone of Paiva pond. Snails were collected with a perforated dipper, 12.5 $\mathrm{cm}$ in diameter, and their relative abundance was estimated as number of individuals collected per hour. Size was measured by maximum shell diameter. Methodologies used for gastropod collection and for measurement of $\mathrm{pH}$, conductivity, concentration and percentage of oxygen saturation, and water temperature are given by Rumi and Hamann (1992) and Hamann et al. (1993).

Age structure and growth rates: for graphic representation of age structure relative to size, individual diameter data were grouped in $1 \mathrm{~mm}$ class interval and 7 age classes in D. lucidum (Museo de La Plata, La Plata, Argentina -MLP-, $\mathrm{n}^{\circ} 7388$ ) and 10 age classes in D. depressissimum (MLP $\mathrm{n}^{07389}$ ). Each cohort was assumed to be representative of one generation resulting from a specific reproductive period and its mean; standard deviation and number of individuals were calculated.

Application of von Bertalanffy's model was based on the methodology of Basso and Kehr (1991). Time corresponding to each sampling was calculated from the equation: $\mathrm{t}=[(\mathrm{m}-1) 30+\mathrm{d}] 360^{-1}$, where $\mathrm{m}=$ month and $\mathrm{d}=$ sampling date. Here, $\mathrm{t}=1$, approximately one year (1.002). The von Bertalanffy model was applied in both species: $\mathrm{Lt}=\mathrm{L}_{\max }$ $\left(1-\mathrm{e}^{-\mathrm{k}(\mathrm{t}-\mathrm{to})}\right)$, where: $\mathrm{Lt}=$ size at time $\mathrm{t} ; \mathrm{L}_{\max }=$ asymptotic maximum size; to $=$ hypothetic at time when size is equal to "zero"; $t=$ time; $k=$ constant growth rate. By linear transformation of the logarithmic equation we obtained: $\ln \left(1-(\mathrm{Lt}) \mathrm{L}_{\max }{ }^{-1}\right)=-\mathrm{kt}+\mathrm{kto}(1)$. A regression equation between $\ln \left(1-(\mathrm{Lt}) \mathrm{L}_{\max }{ }^{-1}\right)$ (dependent variable) and $t$ (independent variable), was calculated. In (1), $\mathrm{kto}=$ origin of ordinate (a), to $=(a) k^{-1}$, and the slope $(b)=(-) k$. Significant differences among regressions were estimated on the basis of their confidence limits. $\mathrm{L}_{\max }$ is the largest size found in individuals of each species. Theoretical curves obtained were compared, using a $\chi^{2}$ test, to size found in nature.

Interspecific comparisons: to compare individual growth curves among species in different conditions, the results of Rumi et al. (2004) for D. kermatoides (MLP $\mathrm{n}^{\circ} 6798$ ) and D. cimex (MLP $\mathrm{n}^{\circ} 6757$ ), inhabiting environments of the IMG, Río de la Plata $\left(34^{\circ} 11^{\prime} \mathrm{S}\right.$; $58^{\circ} 15^{\prime} \mathrm{W}$ ), were included. In the model, fitness criteria were used: expected sizes according to the growth model were expressed into a percentage of their maximum size. In these cases, beginning of all cohorts were taken as "to" 0 which allowed them to become independent of the real or estimated starting date for each cohort.

\section{RESULTS}

Analysis of Drepanotrema spp. age structures in the Paiva pond: D. lucidum: a large percentage of individuals in the first two age classes (recruitment) and juveniles (age classes 3-4) were observed towards the end of autumn. High percentages of adults were also observed between autumn and spring (Fig. 2).

D. depressissimum: a high percentage of individuals of the first sizes and adults were 


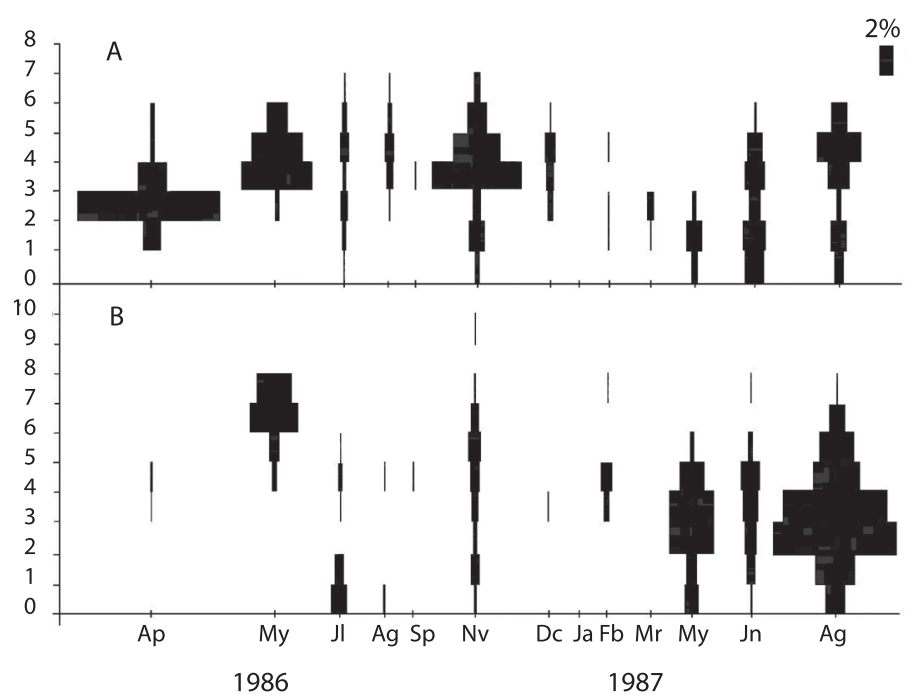

Fig. 2. Age structures of D. lucidum (A) and D. depressissimum (B).

Fig. 2. Estructura de edades para D. lucidum (A) y D. depressissimum (B).

observed in autumn and spring. In winter, all age classes were present, dominated by individuals of age classes 3 and 4 (Fig. 2).

Conductivity varied through the year (40 to $130 \mu \mathrm{S} \mathrm{cm} \mathrm{cm}^{-1}$ ). The percentage of oxygen saturation fluctuated with no defined seasonal pattern. $\mathrm{pH}$ was slightly below neutral. Water temperatures were never below $10^{\circ} \mathrm{C}$ (Fig. 3A, B, C, D).

Growth analysis: maximum size observed for $D$. lucidum was 6.9 and $9.38 \mathrm{~mm}$ for $D$. depressissimum. The growth model fitted well $(\mathrm{p}>0.05)$ for the cohorts of both species $(D$. lucidum: autumn: $\chi^{2}$ : 0.0672, df: 5; spring: $\chi^{2}$ : 0.3580 , df: $6 ; D$. depressissimum: summer: $\chi^{2}$ : 0.2250, df: 5; autumn: $\chi^{2}: 0.0725$, df: 4; spring: $\chi^{2}: 0.0111$, df: 2 ). Determination coefficients $\left(\mathrm{R}^{2}\right)$ for each cohort were higher than 0.86 (Table 1). The curves did not show statistically significant differences, according to the confidence limits $(p>0.05)$ obtained of each regression equation (where $\mathrm{k}=\mathrm{-b}$ ). However, growth rates of spring cohorts, for both species, were higher (Fig. 4, 5 and 6).
Rates and interspecific growth patterns: winter cohorts were not observed (Table 2), except for a population of $D$. kermatoides (IMG) found towards the end of winter. There were no statistically significant differences in growth rhythm among species in Paiva pond and the IMG habitats, independently of the start of the cohorts and their maximum size. IMG conductivity data (Fig. 7) were divided into two groups, given the differences between the mean values of the different environments: Group $1\left(>650 \mu \mathrm{S} \mathrm{cm} \mathrm{cm}^{-1}\right.$, Tank and Big Quarries) and Group $2\left(<500 \mu \mathrm{S} \mathrm{cm}{ }^{-1}\right.$, Rubbish and Buoy Quarries, Intangible Zone and Stream). Values from the second group are similar to those observed in IMG coastal waters as Río de la Plata ( 85 to $143.2 \mu \mathrm{S} \mathrm{cm}^{-1}$ ) and in the Paiva pond ( 31 to $270 \mu \mathrm{S} \mathrm{cm} \mathrm{cm}^{-1}$ ). Highest growth rates for Drepanotrema were observed in D. cimex and D. kermatoides, environments with the highest conductivity at IMG (Group $1)$, where oxygen concentration $\left(0.2-2 \mathrm{mg} \mathrm{l}^{-1}\right)$ and oxygen availability were low.

Comparing circannual and biannual growth rhythms (showed as percentages) (Fig. 


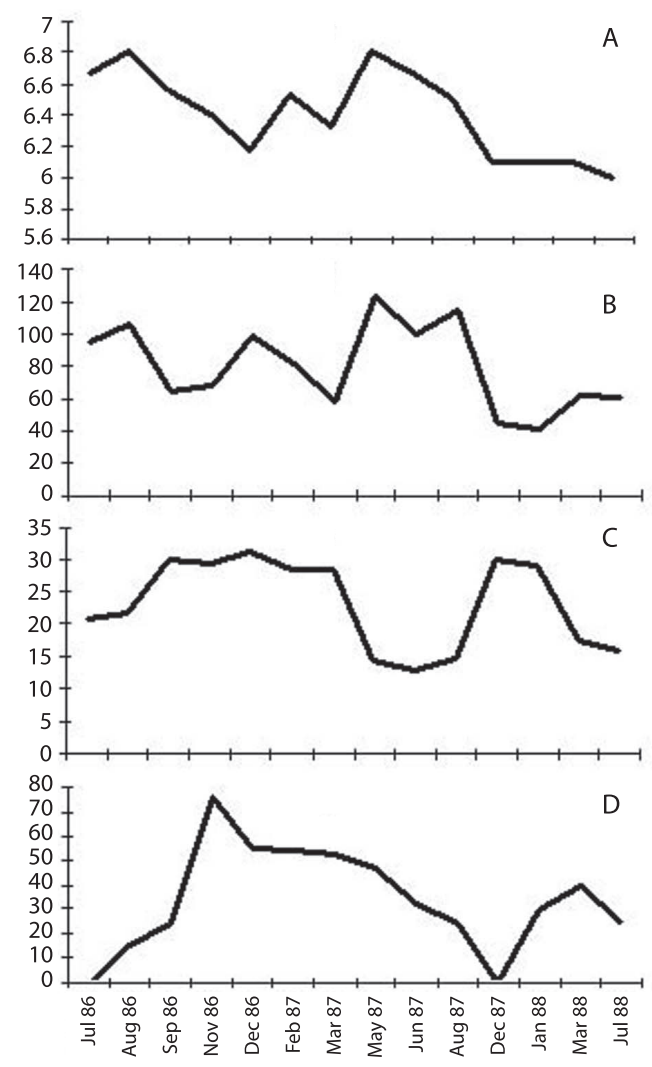

Fig. 3. A. $\mathrm{pH}$; B. conductivity $\left(\mu \mathrm{S} \mathrm{cm}^{-1}\right)$; C. percentage of dissolved oxygen; and D. temperature values $\left({ }^{\circ} \mathrm{C}\right)$, recorded in the Paiva pond.

Fig. 3. A. $\mathrm{pH}$; B. conductividad $\left(\mu \mathrm{S} \mathrm{cm}^{-1}\right)$; C. porcentaje de oxígeno disuelto; y D. temperatura $\left({ }^{\circ} \mathrm{C}\right)$, registradas en la laguna Paiva.

8) we found that most species reached $60 \%$ of their development at an age of one year $(D$. lucidum: between 72.8-74.5\%; D. depressissimum: 73.8-77.8 \%; D. kermatoides: $62.5-81.7$ $\%$ and D. cimex: $64.8-83.9 \%$ ), and $85 \%$ of their development or more at an age of two years (D. lucidum: 92.6-93.5 \%; D. depressissimum: 93.1-95.1\%; D. kermatoides: 85.9-96.6 $\%$ and D. cimex: 87.6-97.3 \%).

\section{DISCUSSION}

In Paiva pond the constantly high environmental temperature (above $20^{\circ} \mathrm{C}$ ) and partial seasonal desiccation (Rumi and Hamann
TABLE 1

Von Bertalanffy's model parameters for D. lucidum and $\mathrm{D}$. depressissimum ${ }^{1}$ under natural conditions.

\section{CUADRO 1}

Valores de los parámetros del modelo de von Bertalanffy obtenidos en condiciones naturales para D. lucidum $y$ D. depressissimum ${ }^{2}$

Drepanotrema lucidum

$\begin{array}{ccccc} & \text { "to" } & \mathrm{R} 2 & \mathrm{~N} & \mathrm{k} \\ \text { A. } & 0.30 & 0.96 & 384 & 1.30 \\ \text { S. } & 0.82 & 0.86 & 816 & 1.37\end{array}$

Drepanotrema depressissimum

$\begin{array}{ccccc} & \text { "to" } & \text { R2 } & \text { N } & \text { k } \\ \text { Su. } & 0.17 & 0.88 & 606 & 1.45 \\ \text { A. } & 0.36 & 0.99 & 1244 & 1.34 \\ \text { S. } & 0.78 & 0.99 & 58 & 1.51\end{array}$

1. "to"= hypothetical time at which individuals' length= $0 ; \mathrm{R} 2=$ determination coefficient; $\mathrm{N}=$ number of individuals at each station; $\mathrm{k}=$ growth constant; $\mathrm{Su}$.: Summer; A.: Autumn; S.: Spring.

2. "to"= tiempo hipotético en el que los individuos poseen una longitud cero; R2= coeficiente de determinación; $\mathrm{N}=$ número de individuos en cada estación; k= constate de crecimiento; Su.: Verano; A.: Otoño; S.: Primavera.

TABLE 2

Calculated beginning of cohorts for Drepanotrema species in the Paiva pond and at Isla Martin Garcia during the different seasons of a year ${ }^{1}$

\section{CUADRO 2}

Inicio de la cohortes halladas para las especies de Drepanotrema en la laguna Paiva y la Isla Martín García durante las diferentes estaciones climáticas del año ${ }^{2}$

Cohorts Su. A. W. S.

D. depressissimum $\quad+\quad+\quad+$

D. lucidum + +

D. cimex ++

D. kermatoides + + +

1. Su.: Summer; A.: Autumn; W.: Winter; S.: Spring; *: End of winter.

2. Su.: Verano; A.: Otoño; W.: Invierno; S.: Primavera; *: Fines de invierno. 


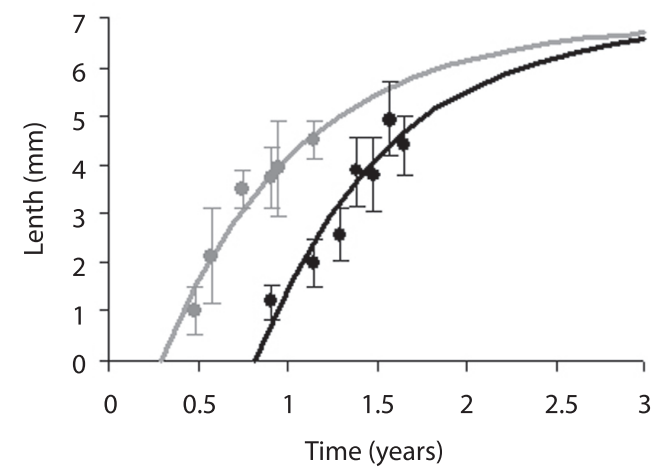

Fig. 4. Growth curves of D. lucidum in the Paiva pond. Solid dots, mean length observed; dashes, SD; black line: spring; gray line: autumn. Time unit: year.

Fig. 4: Curvas de crecimiento para D. lucidum en la Laguna Paiva. Puntos: longitud media observada; guión: DS; línea negra: primavera; línea gris: otoño. Unidad de tiempo: años.

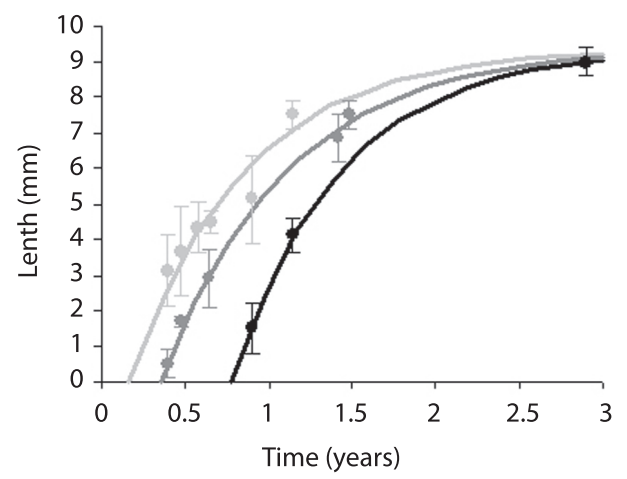

Fig. 5. Growth curves of $D$. depressissimum in the Paiva pond. Solid dots, mean length observed; dashes, SD; black line: spring; gray line: autumn; gray clear line: summer. Time unit: year.

Fig. 5. Curvas de crecimiento para D. depressissimun en la Laguna Paiva. Longitud media observada; guión: DS; línea negra: primavera; línea gris: otoño; línea gris clara: verano. Unidad de tiempo: años.

1992) inhibited reproduction. In January, no snails were found, and in February, they were scarce. Predominant size in both species corresponded to adult specimens. Moreover, estimated starting times of cohorts of both species showed a tendency towards asynchronous displacement, allowing to alternate recruitment

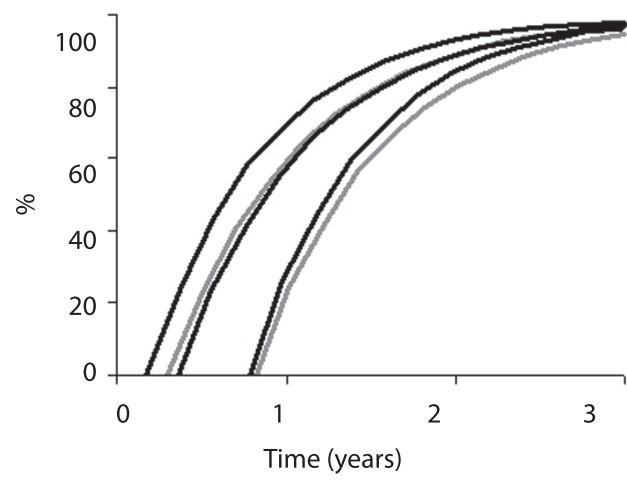

Fig. 6. Growth curves for Drepanotrema species of the Paiva pond, showed as percentages of their maximum length starting at "to" $=0$. Black lines: $D$. depressissimum; gray lines: D. lucidum. Time unit: year.

Fig. 6. Curvas de crecimiento para las especies de Drepanotrema en la Laguna Paiva, expresadas en porcentaje de su longitud máxima iniciando en 0 . Líneas negras: D. depressissimun; líneas grises: D. lucidum. Unidad de tiempo: años.

periods. This strategy may decrease competition for plant substrate that functions as food and as oviposition sites. D. depressissimum showed a longer period of recruitment than D. lucidum, which may be considered more independent from the seasons.

D. kermatoides showed high tolerance to environmental stress and an affinity for free-floating macrophytes at the Big Quarry (IMG), in agreement with observations in urban environments of Chaco (Rumi et al. 2002). Specific data on ammonium and phosphorus (220-375 $\mu \mathrm{g} \mathrm{l}^{-1}$ and $1020-2630 \mu \mathrm{g} \mathrm{l}^{-1}$, respectively) and low nitrates (4-14 $\mu \mathrm{g} \mathrm{l}^{-1}$ ), indicate a prevalence of decomposition of the dense macrophyte cover.

Highest growth rates were observed in $D$. kermatoides and D. cimex cohorts from IMG towards the end of spring and beginning of summer $(\mathrm{k}=1.7-1.8)$. Species of the Paiva (D. lucidum and D. depressissimum) showed growth rhythms near medium values (k: 1.31.5). Comparing environments close to the coast of IMG and to the Paiva pond (Fig. 8) we found that in Paiva, growth rates were higher. However, here mean conductivities were lower 

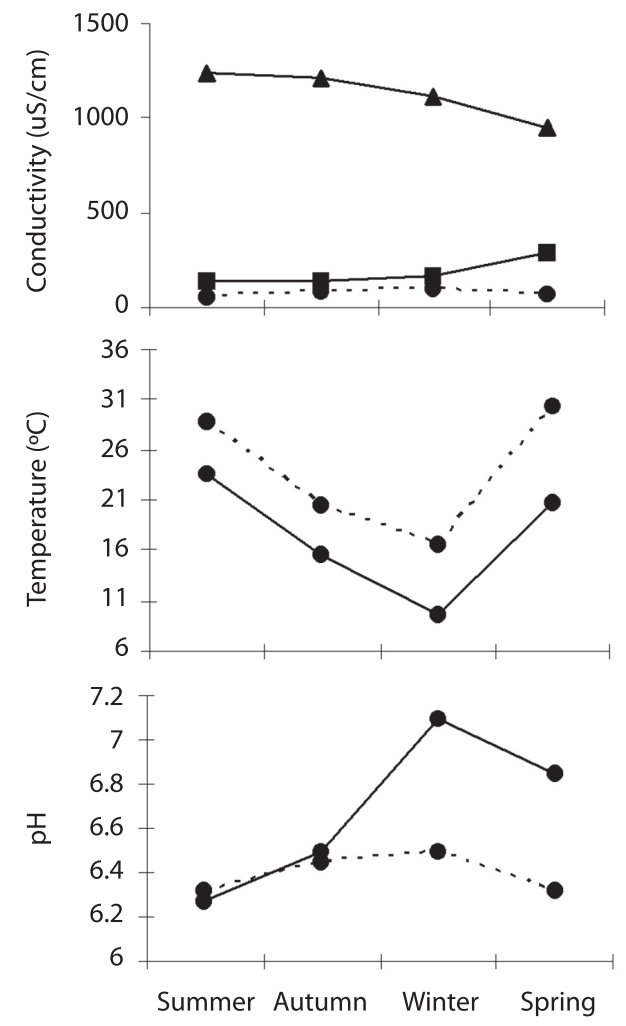

Fig. 7. Comparison of environmental parameters between the Paiva pond (dashed) and Isla Martín García (continuous lines). For conductivities, IMG data were divided into two groups: solid triangles Group 1 IMG and solid squares Group 2 IMG.

Fig. 7. Comparación de parámetros ambientales entre la Laguna Paiva (líneas entrecortadas) y la Isla Martín García (líneas continuas). Para las conductividades los datos de la IMG se dividieron en dos grupos: triángulos: Grupo 1 IMG y cuadrados Grupo 2 IMG.

through the year than those of IMG. At similar conductivity values, a higher temperature and more available oxygen contribute to a higher growth rate, as observed in Paiva. However, extreme summer temperatures produced an important desiccation and a strong regulating effect of Drepanotrema populations (see in Fig. 2, absence of snails in January). In summary, apart from D. kermatoides, the species could not endure environmental stress. Accelerated growth-rates in the first year, could

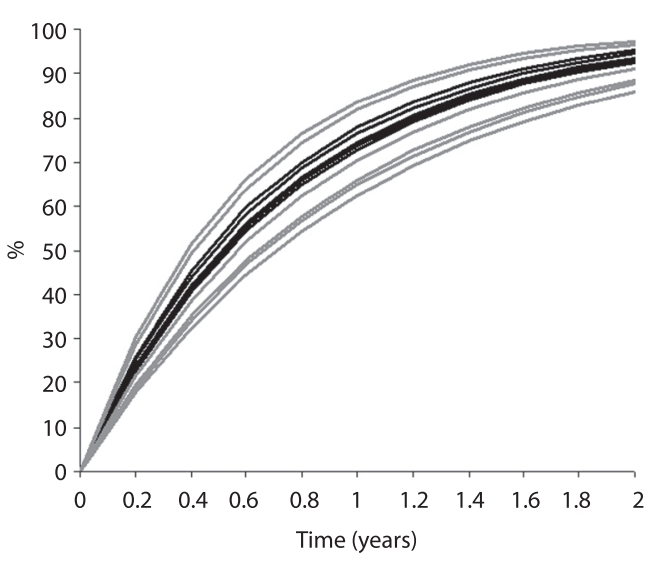

Fig. 8. Growth curves of the different seasonal cohorts for the species of Drepanotrema (D. lucidum; D. depressissimum; D. kermatoides and D. cimex) inhabiting Paiva pond (black lines) and IMG (gray lines). On the ordinates, the percentage relationship of expected sizes and maximum length, according to the growth model at each time unit (year), is indicated. Cohorts start at "to" $=0$.

Fig. 8. Curvas de crecimiento de las distintas cohortes estacionales para las especies de Drepanotrema (D. lucidum; $D$. depressissimum; D. kermatoides y $D$. cimex) que habitan la laguna Paiva (líneas negras) e IMG (líneas grises). En las ordenadas se indica la relación porcentual respecto a la talla y longitud máxima de acuerdo con el modelo de crecimiento en cada unidad de tiempo (años). El inicio de todas las cohortes fueron llevadas a 0 .

be a strategy to decrease the negative effects of degrading environmental processes. The Paiva could be considered as more favorable for growth and population development since summer desiccation is restricted.

In Guadalupe (West Indies), Lévèque and Pointier (1976) observed that two sampling stations had a water temperature of $25-27^{\circ} \mathrm{C}$. One was inhabited by $D$. depressissimum and the other by $D$. lucidum. Both Drepanotrema spp. showed high growth rates and become almost fully grown in one month. Both Drepanotrema spp. have natural populations from Caribbean areas to the Argentinian Mesopotamia Region. D. depressissimum reaches the southern distribution at Buenos Aires province, Argentina (Baker 1945, Rumi et al. 1997). The annual average temperature in Paiva pond is about $24{ }^{\circ} \mathrm{C}$ (Range $=11$ to $31{ }^{\circ} \mathrm{C}$ ), although it 
reaches high water temperatures (about $30^{\circ} \mathrm{C}$ ). It shows large annual fluctuations, and if the temperature gradient is correlated with growth trends, the growth of $D$. depressissimum and $D$. lucidum populations is expected to be slower in southern areas than in tropical areas.

On the other hand, a similar time scale was used to compare $\mathrm{k}$ values, because they are sensitive to that scale. Most of the scales used are in weeks (52 per year), months (12 per year) or year fractions $(1$ year $=1)$. For example, using the same population data, we obtained: for a weekly scale, $\mathrm{k}=0.0216$; for a monthly scale, $\mathrm{k}=0.09$ and for year fractions scale, $\mathrm{k}=1.1366$. These $\mathrm{k}$ values are not comparable. However, if growth is expressed as percentages of the maximum size, comparisons can be done. In our example, independently of the scale used, the population reached $67 \%$ of its maximum size during the first year. In this way, this last evaluation allows better comparisons among species, with different sizes and from different environments.

\section{ACKNOWLEDGMENTS}

Research was supported by Facultad de Ciencias Naturales y Museo, Universidad Nacional de La Plata, Agency of Scientific Promotion (BID 1201/OC-AR PICT 01-03453) and Consejo Nacional de Investigaciones Científicas y Técnicas (CONICET) (PIP 2711), Argentina. We specially thank D. Taylor for checking the English and for suggestions.

\section{RESUMEN}

En Argentina se encuentran seis especies del género Drepanotrema. El ciclo de vida en sistemas naturales de Drepanotrema depressissimu y D. lucidum ha sido muy poco estudiado, excepto por algunas observaciones aisladas. El objetivo de este estudio es analizar las principales tendencias de la población en la Laguna Paiva, Argentina. Usamos modelos de crecimiento y metodologías comparativas entre las especies y los ambientes en Paiva y la isla Martín García (IMG). Además, las curvas teóricas del modelo de von Bertalanffy para cada población fueron contrastadas con las muestras utilizando la prueba $\chi^{2}$. Los tamaños esperados fueron transformados en porcentajes de tamaño máximo y las cohortes se iniciaron a partir del tiempo cero, lo cual les permitió ser independientes de la fecha inicial real o estimada y con ello ser comparables. Se utilizó una escala de tiempo similar debido a que los valores de $\mathrm{k}$ demostraron ser sensibles a la escala de tiempo. El tamaño máximo alcanzado por D. lucidum fue de $6.9 \mathrm{~mm}$ y por $D$. depressissimun fue de $9.38 \mathrm{~mm}$. Las tasas de crecimiento $(\mathrm{k})$ fluctuaron de 1.302-1.368 en la primera especie y 1.339-1.509 para la segunda especie. No fueron encontradas diferencias significativas en las curvas de crecimiento entre las especies que habitaban en Paiva ni en los diferentes cuerpos de agua de IMG, independientes del inicio de cada cohorte y del tamaño máximo. En general no se observaron cohortes de invierno, excepto en una población de D. kermatoides (IMG). Al comparar los ritmos de crecimiento anuales y semestrales, la mayoría de las especies alcanzaron el $60 \%$ de su desarrollo durante el primer año y el $85 \%$ ó más durante su segundo año.

Palabras clave: tasa de crecimiento, Drepanotrema spp., Planorbidae, Argentina, Cuenca del Plata.

\section{REFERENCES}

Baker, F.C. 1945. The Molluscan Family Planorbidae. Illinois, Illinois, USA. 530 p.

Baluku, B. \& M. Loreau. 1989. Étude comparative de la dynamique des populations de Biomphalaria pfeifferi (Gastropoda: Planorbidae) dans deux cours d'eau du Zaïre oriental. Rev. Zool. Afr. 103: 311-325.

Basso, N.G. \& A.I. Kehr. 1991. Postmetamorphic growth and population structure of the frog Leptodactylus latinasus (Anura: Leptodactylidae). Stud. Neotrop. Fauna Envir. 26: 39-44.

Boltovskoy, D. \& D.H. Cataldo. 1999. Population dynamics of Limnoperna fortunei, an invasive fouling mollusc, in the lower Paraná River (Argentina). Biofouling 14: 255-263.

Bonetto, A.A., M.A. Corrales, M.E. Varela, M.M. Rivero, C.A. Bonetto, R.E. Vallejos \& Y. Zalokar. 1978a. Estudios limnológicos en la cuenca del Riachuelo. II. Laguna Totoras y González. Ecosur 5: 17-55.

Bonetto, A.A., D. Roldán \& M.E. Oliver. 1978b. Estudios limnológicos en la cuenca del Riachuelo (Corrientes, Argentina). I. Poblaciones de peces en ambientes leníticos y lóticos. Ecosur 5: 1-15. 
Bonetto, A.A., J.A. Bechara \& M.P. Tassara. 1982. Los moluscos de la familia Planorbidae en el área del río Paraná medio. Physis sec. B 41: 1-6.

Bonetto, A.A., A. Rumi \& M.P. Tassara. 1990. Notas sobre el conocimiento limnológico de los gasterópodos paranenses y sus relaciones tróficas. II. Planorbidae, con aspectos distribucionales y sanitarios. Ecosur 16: $69-84$.

Cataldo, D. \& D. Boltovskoy. 1999. Population dynamics of Corbicula fluminea (Bivalvia) in the Paraná river delta (Argentina). Hydrobiologia 380: 153-163.

Colautti, D.C. 1997. Ecología de la carpa Cyprinus carpio, en la cuenca del Río Salado, Provincia de Buenos Aires. Tesis de doctorado, Universidad Nacional de La Plata, Buenos Aires, Argentina.

Costil, K. \& J. Daguzan. 1995. Comparative life cycle and growth of two freshwater gastropod species, Planorbarius corneus (L.) and Planorbis planorbis (L.). Malacologia 37: 53-68.

Darrigran, G. \& M.E. Maroñas. 1989. Crecimiento de las poblaciones naturales de Corbicula fluminea (Muller, 1774) y C. largillierti (Philippi, 1844) (Bivalvia: Sphaeriacea) en el litoral de Punta Blanca, estuario de Río de la Plata, República Argentina. Com. Soc. Malac. Urug. 56-57: 139-157.

Eleutheriadis, N. \& M. Lazaridou-Dimitriadou. 1995. The life cycle, population dynamics, growth and secondary production of the snail Viviparus contectus (Millet) (Gastropoda: Prosobranchia) in the marshes of the river Strymonas, Serres, Macedonia, Northern Greece. Malacologia 37: 41-52.

Ferrer, J., G. Perera, M. Yong Cong \& O. Amador. 1989. Life tables of Fossaria cubensis and Pseudosuccinea columella, intermediate hosts of Fasciola hepatica in Cuba. J. Med. Appl. Malacol. 1: 189-194.

Hamman, M.I., A. Rumi \& M. Ostrowski de Núñez. 1993. Aspectos biológicos sobre los parásitos y la dinámica poblacional de Drepanotrema spp. (Mollusca, Planorbidae) en un biotopo lenítico del nordeste argentino. Amb. Subtrop. 3: 19-38.

Ituarte, C.F. 1985. Growth dynamics in a natural population of Corbicula fluminea (Bivalvia: Sphaeriacea) at Punta Atalaya, Río de la Plata, Argentina. Stud. Neotrop. Fauna Envir. 20: 217-225.

Lévêque, C. \& J.P. Pointier. 1976. Study of the growth of Biomphalaria glabrata (Say) and other Planorbidae in Guadalupe (West Indies). Ann. Trop. Med. Parasitol. 70: 199-204.
Paraense, W.L. 1980. Drepanotrema cimex: synonimy, variation and geographical distributions (Mollusca: Planorbidae). Rev. Brasil. Biol. R. J. 40: 101-113.

Paraense, W.L. \& N. Deslandes. 1958a. The Brazilian species of "Drepanotrema". IV. "D. cimex" (Moricand, 1837). Rev. Brasil. Biol. R. J. 18: 187-192.

Paraense, W.L. \& N. Deslandes. 1958b. The Brazilian species of "Drepanotrema". VI. "D. kermatoides" (Orbigny, 1835). Rev. Brasil. Biol. R. J. 18: 293 299.

Perera de Puga, G., J.P. Pointier, M. Yong Cong \& J.L. Ferrer Lopez. 1991. Comparación del crecimiento de dos especies de Pomacea del área antillana, útiles como agente de control de enfermedades tropicales. Rev. Cubana Med. Trop. 43: 36-38.

Pretorius, S.J., K.N. de Kock \& P. Joubert. 1992. Evidence that population growth of the freshwater snail Bulinus africanus is density limited in a natural habitat. J. Med. Appl. Malacol. 4: 113-120.

Rumi, A. 1991. La familia Planorbidae Rafinisque, 1815, en la República Argentina, p. 1-51. In Z. Castellanos (ed.). Fauna de Agua Dulce de la República Argentina. PROFADU (CONICET), Buenos Aires, Argentina.

Rumi, A. \& M.I. Hamann. 1992. Spatial and seasonal trends of a natural population of Biomphalaria occidentalis in northeastern Argentina. Mem. Inst. Oswaldo Cruz 87: 181-186.

Rumi, A., M.P. Tassara \& A.A. Bonetto. 1997. Distribución de las especies de Planorbidae en Argentina y su relación con el riesgo de esquistosomiasis. Ecosur 17: $1-19$

Rumi, A., J.A. Bechara, M.I. Hamann \& M. Ostrowski de Núñez. 2002. Ecology of potential hosts of schistosomiasis in anthropic environments of Chaco, Argentina. Malacologia 44: 273-288.

Rumi, A., D. Gutiérrez Gregoric, M. Roche \& M. Tassara. 2004. Population structure in Drepanotrema kermatoides and D. cimex (Gastropoda: Planorbidae) in natural conditions. Malacologia 45: 453-458.

Sendra, E. \& L. Freyre. 1978. Dinámica poblacional de Bryconamericus iheringi (Pisces: Tetragonopteridae) de la laguna de Chascomús. Limnobios 1: 299-321.

Sendra, E. \& L. Freyre. 1981. Estudio demográfico de Cheirodon interruptus interruptus (Pisces: Tetragonopteridae) de la laguna Chascomús. I. Crecimiento. Limnobios 2: 111-126. 
